\title{
An overview of lithotype associations of Miocene lignite seams exploited in Poland
}

\author{
Marek Widera \\ Institute of Geology, Adam Mickiewicz University, 12 Krygowski St., 61-680 Poznań, Poland; \\ e-mail: widera@amu.edu.pl
}

\begin{abstract}
Currently, three stratigraphically distinct lignite seams of Early to Middle Miocene age are exploited in Poland, namely the third Ścinawa lignite seam (ŚLS-3), the second Lusatian lignite seam (LLS-2) and the first Mid-Polish lignite seam (MPLS-1). All of these are composed of numerous macroscopically distinguishable layers defined as lignite lithotypes. In the present paper, the lithotypes of Polish lignites are grouped into seven major lithotype associations that originated in various types of mire. Therefore, an approximate reconstruction of mire type can be based on lignite lithotypes. Within the Polish lignite seams examined, the commonest in order of importance are: xylodetritic (XDL), detroxylitic (DXL), detritic (DL) and xylitic (XL) lithotype associations, mostly with a massive (m) or horizontal (h) structure. They are particularly dominant in lignite opencasts belonging to the Konin and Adamów mines. However, in the lowermost seams at the Turów and Bełchatów mines, a substantial part of the seams comprises the bitumen-rich (BL) lithotype association. These seams also lignite lithotypes that in large quantities have a gelified (g) and/or nodular (n) structure. In contrast, lignites from the Sieniawa mine are characterised by an admixture of the best-developed lithotype associations of both fusitic (FL) and weathered (WL) lignites. Moreover, the vast majority of these lignites have a folded (fo) and/or faulted (fa) structure, because they were completely deformed by glaciotectonics.
\end{abstract}

Keywords: brown coal, Cenozoic, northern Europe, lithotypes

\section{Introduction}

Poland is one of the most significant lignite producers, ranking second in the European Union and fourth worldwide, with an annual extraction of about 63-66 Mt. Therefore, lignite plays a key role in electricity production, supplying $30-33 \%$ of Poland's total electricity, that is, about 53-55 TWh (Pietraszewski, 2015).

Currently, Polish lignite production is conducted at four large mines and a single small one, in nine opencasts. The largest are the Adamów Lignite Mine with the Adamów and Koźmin N opencasts, the Bełchatów Lignite Mine with the Bełchatów and Szczerców opencasts, the Konin Lignite Mine with the Jóźwin IIB, Drzewce and Tomisławice opencasts and the Turów Lignite Mine with the Turów opencast. The smallest is the Sieniawa Lignite Mine with the Sieniawa opencast (Fig. 1).

Taking into account the size of lignite production and number of opencasts, it can be stated that the Polish lignite mines provide an excellent opportunity to examine lignite seams in detail. The seams exploited vary in age and, in some cases, belong to the thickest in Europe and around the world. These lignite seams also differ petrographically; that is, they consist of various lithotypes (e.g., Brzyski, 1981; Wagner, 1996; Kwiecińska \& Wagner, 1997; Majewski, 2002; Kasiński et al., 2010; Widera, 2007, 2012; Nowak, 2012; Bielowicz, 2013; Fabiańska \& Kurkiewicz, 2013; Bielowicz \& Kasiński, 2014).

The major aims of this paper are threefold: 1) to present a brief, lucid explanation of how to distinguish and describe lignite lithotypes within 
a lignite seam in the field; 2) to provide examples of the most interesting lignite lithotypes from the exploited Polish lignite seams; and 3) to reconstruct the mire type based on the resultant lignite lithotypes. A secondary goal of this research is to discuss the relationship between lignite lithotypes and the stratigraphical position of the lignite seam as well as between lignite lithotypes and the location of the lignite-bearing area within Poland.

\section{Geological setting}

Lignite mining is concentrated in five areas of central and western Poland (Fig. 1). This is due to the fact that almost all lignite deposits of economic value are located in the same territories (e.g., Ciuk \& Piwocki, 1990; Kasiński \& Piwocki, 2002). Generally, the lignite-bearing areas cover approximately $70,000 \mathrm{~km}^{2}$, that is, about one-third of the Poland's total territory (Piwocki, 1992). On the other hand, the minable geological resources of 90 of the largest Polish lignite deposits were determined to be more than 23.5 Gt at the end of 2014 (Szuflicki et al., 2015).

Most of Poland, inclusive of the lignite-bearing areas, belongs to the northwest European Paleogene-Neogene Basin (Vinken, 1988). Due to poverty of other palaeontological remains, lignite seams play a key stratigraphic role especially in the case of the Neogene deposits. This makes it possible to correlate the organic-rich deposits from western Poland with those from eastern Germany (compare Piwocki \& Ziembińska-Tworzydło, 1997; Widera et al, 2008). Thus, the mined Polish seams, that is, the third Ścinawa lignite seam (ŚLS-3), the second Lusatian lignite seam (LLS-2), and the first Mid-Polish lignite seam (MPLS-1) match the German third, second, and first Lusatian lignite seams, respectively (compare Grimm et al., 2002; Widera, 2016a).

These lignite seams are of Early and Middle Miocene age (Fig. 2). They all cover areas that subsided tectonically at that time. In other words, the investigated lignite seams mostly fill grabens, which range in depth from a few dozen metres to more than 500 m (Kasiński, 2000; Wagner et al., 2000; Widera, 2007, 2016b; Kasiński et al., 2010; Widera \& Hałuszczak, 2011). The oldest third Ścinawa lignite seam (ŚLS-3) is currently exploited in the Bełchatów, Szczerców and Turów opencasts. The second Lusatian lignite seam (LLS-2) comprises the uppermost parts of the mined seams in the same opencasts, and additionally it is also exploited in the Sieniawa opencast mine. Conversely, the first Mid-Polish lignite seam (MPLS-1) is now excavated only in all of the opencasts belonging to the Adamów and Konin lignite mines (Figs. 1, 2; Widera, 2016a).

Polish lignite deposits are among the genetically most differentiated in the world (Ciuk, 1968;

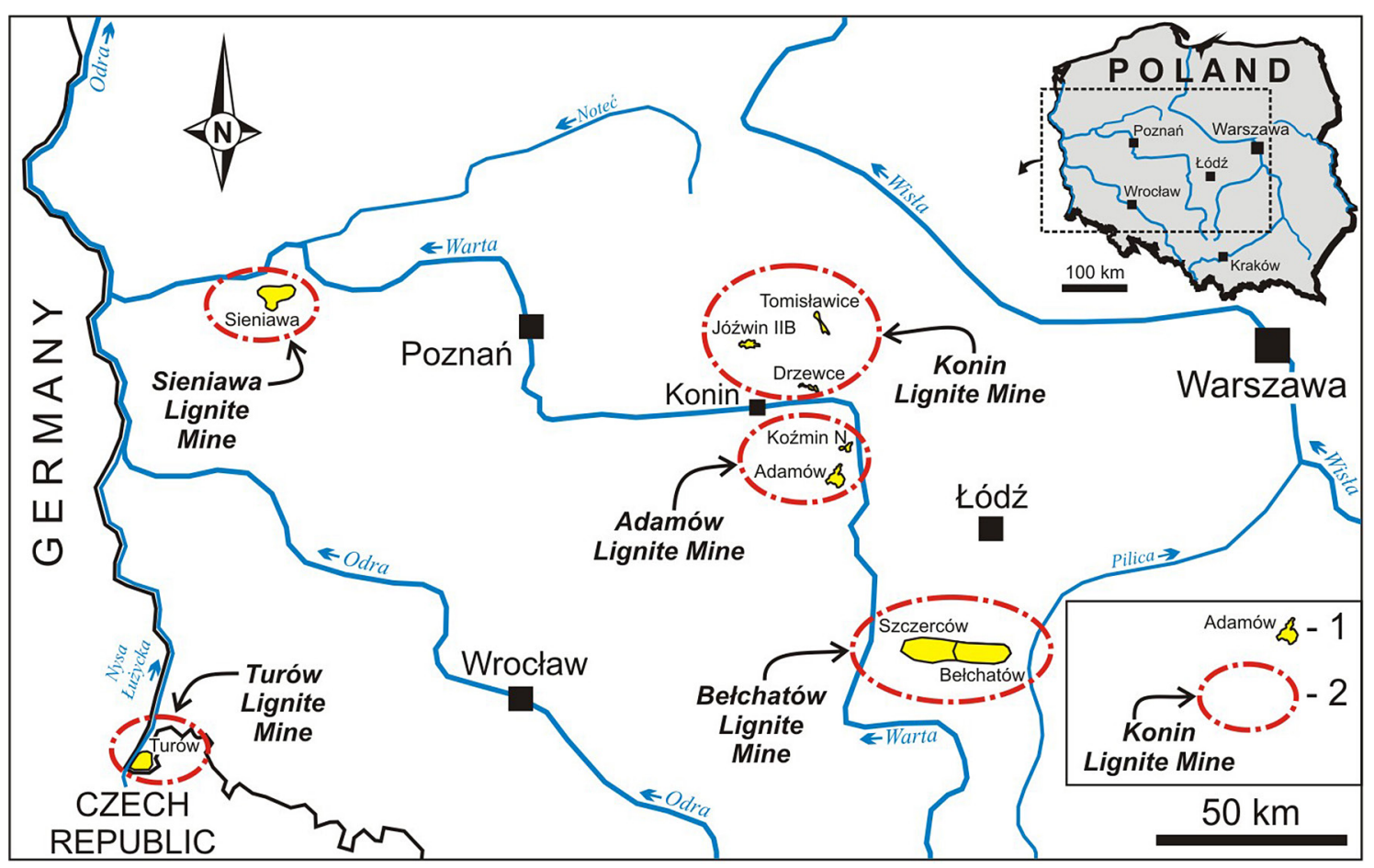

Fig. 1. Locality map. 1 - currently operated lignite opencast mines in Poland; 2 - area of operating Polish lignite mine. 


\begin{tabular}{|c|c|c|c|c|c|}
\hline opencast mine & $\begin{array}{c}\text { Bełchatów } \\
\text { and Szczerców } \\
\text { opencast } \\
\text { mines }\end{array}$ & $\begin{array}{l}\text { Turów } \\
\text { opencast } \\
\text { mine }\end{array}$ & $\begin{array}{c}\text { Sieniawa } \\
\text { opencast } \\
\text { mine }\end{array}$ & $\begin{array}{l}\text { Adamów, Drzewce, } \\
\text { Jóźwin IIB, Koźmin N } \\
\text { and Tomisławice } \\
\text { opencast mines }\end{array}$ & $\underbrace{\text { lignite }}_{\text {seam name }}$ \\
\hline $\begin{array}{l}\text { Middle } \\
\text { Miocene }\end{array}$ & & & & 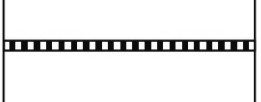 & $\begin{array}{l}\text { the first Mid-Polish } \\
\text { lignite seam } \\
\text { (MPLS-1) }\end{array}$ \\
\hline $\begin{array}{l}\text { Lower } \\
\text { Miocene }\end{array}$ & & & & & $\begin{array}{l}\text { the third Ścinawa } \\
\text { lignite seam } \\
\text { (ŚLS-3) }\end{array}$ \\
\hline
\end{tabular}

Fig. 2. Schematic stratigraphical position of currently exploited lignite seams in Poland (according to Piwocki \& Ziembińska-Tworzydło, 1997; modified). For location of the currently operating lignite opencast mines see Figure 1.

Kasiński \& Piwocki, 2002; Widera, 2016b). In some cases, the lignite seams vary in thickness from a few metres to more than 250 m (Piwocki, 1992; Widera, 2016b). All lignites exploited represent humic low rank coal, i.e. ortholignite (Kwiecińska \& Wagner, 1997, 2001). On the other hand, palynological data, the relatively high mean ash yield (between 7.7 and $22.9 \%$, calculated on a dry basis), and the lithotype associations (described in detail in the present paper) provide evidence that the predominant part of the Polish lignites formed in low-lying mires (e.g., Kasiński et al., 2010; Widera, 2012, 2016a; Mastej et al., 2015).

\section{Methods}

Macroscopic observations and measurements of lignite constituents have been made on two-dimensional surfaces, that is, on lignite quarry surfaces. It should be clearly stated that these actions must be conducted only in the field on fresh lignite surfaces. Thus, this method can be simply illustrated in three steps (Fig. 3).

In the first step, on the basis of clearly visible textural (position, size and number of xylites, differences in colour, mineral intercalations, etc.) and structural features (massiveness, type of stratification, deformations, etc.), boundaries of layers (L1, L1, L3) are determined (Fig. 3A).

The second step is to measure the xylite length within the lignite layer examined. In order to obtain more representative data, it is proposed to make the measurements, for example, along three parallel lines (Fig. 3B). This is certainly the most important step in determining the lithotype. Of course, the difference between the total thickness of the layer analysed and the total length of xylites gives the total length of a detrital matrix.
In the third step, after adding the lignite structure, the lithotype may be appropriately named. In this case, the so-called ' $10 \%$ rule' is commonly used by European lignite researchers. This was also recommended by the ICCP (International Committee for Coal Petrology) in 1993 (compare Widera, 2012; Flores, 2013). Finally, the lignite-lithotype codification is suggested to simplify and shorten the full description (Fig. 3C; Table 1).

The first version of lithotype codification, comprising both textural and structural features of lignite, was proposed by the author (Widera, 2012). It is corrected and supplemented in the present paper. Thus, the texture is coded with capital letters and

Table 1. Codification of textural and structural features of lignite lithotype associations (after Widera, 2012; modified and supplemented).

\begin{tabular}{lc}
\multicolumn{1}{c}{ Lithotype texture } & Code \\
\hline xylitic lignite & XL \\
detritic lignite & DL \\
detroxylitic lignite & DXL \\
xylodetritic lignite & XDL \\
bitumen-rich (bituminiferous ${ }^{1}$ ) lignite & BL \\
fusitic lignite & FL \\
\hline weathered lignite & WL \\
\hline \multicolumn{1}{c}{ Lithotype structure } & Code \\
\hline massive & $\mathrm{m}$ \\
\hline horizontally stratified & $\mathrm{h}$ \\
\hline deformed (fractured, folded, faulted) & $\mathrm{d}(\mathrm{fr}, \mathrm{fo}, \mathrm{fa})$ \\
\hline gelified & $\mathrm{g}$ \\
\hline nodular & $\mathrm{n}$ \\
\hline
\end{tabular}

${ }^{1}$ - acc. to Wagner (1996). 

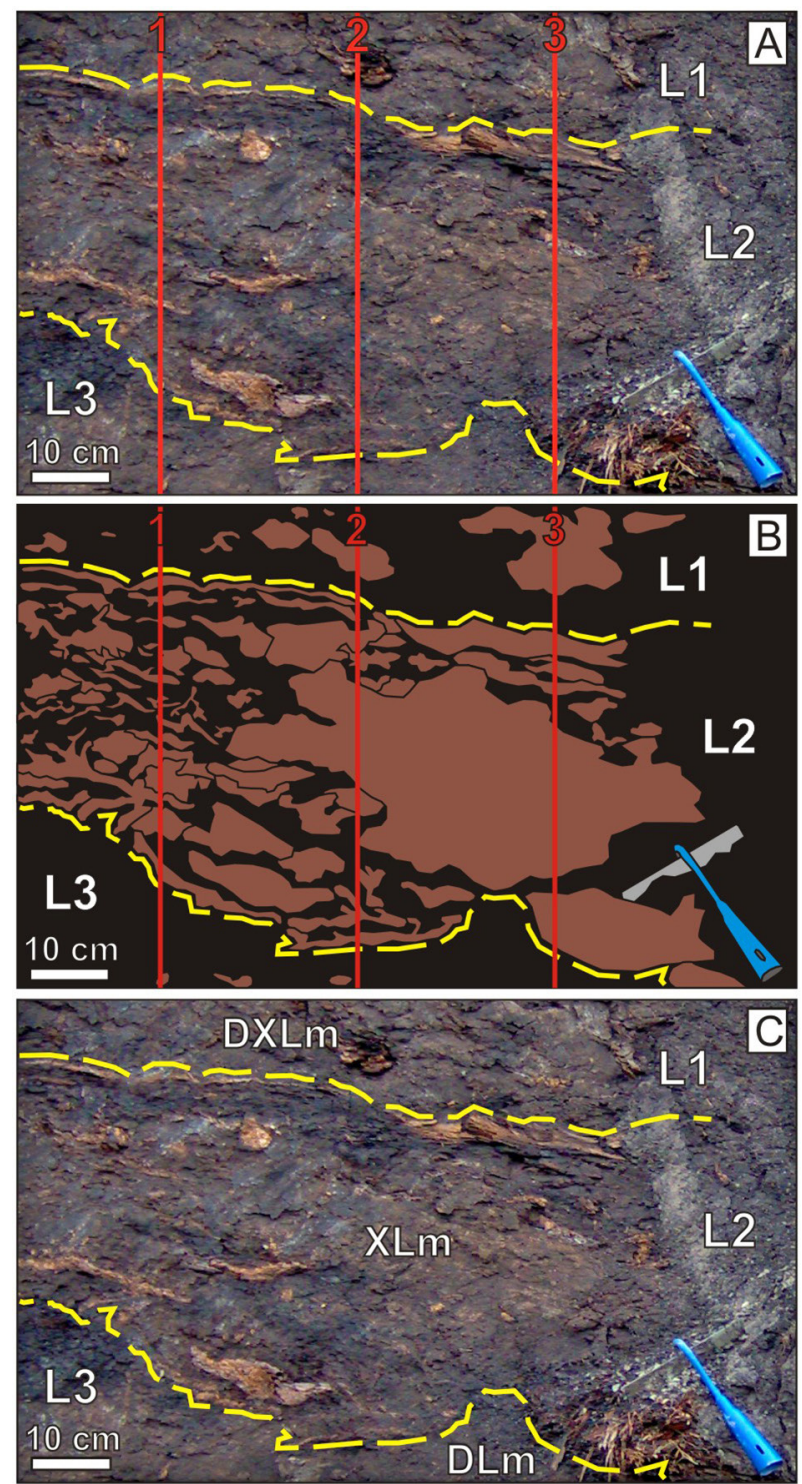

Fig. 3. Illustration of procedures for estimating the relationship between mean (planar) content of xylites and fine-detrital coaly matter using the example of lignite layers that represent the 3rd Ścinawa Lignite Seam (ŚLS-3) in the Bełchatów opencast mine, Bełchatów Lignite Mine. A - Determination (L1, L1, L3) of boundaries between layers and selection of parallel lines $(1,2,3)$ for measurements; $\mathbf{B}$ - Measurements of total xylites and detrital matrix length along parallel lines; C - Description of lithotype name using lignitelithotype codification. For location see Figure 1, for stratigraphical position of lignite seam see Figure 2 and for explanation of lignite lithotype association codes see Table 1.

the structure is coded with lower case letters (Table 1). For more information on the former Polish and international nomenclature and codification of lignite lithotypes reference is made, for example, to the following contributions: Suss \& Sontag (1966),
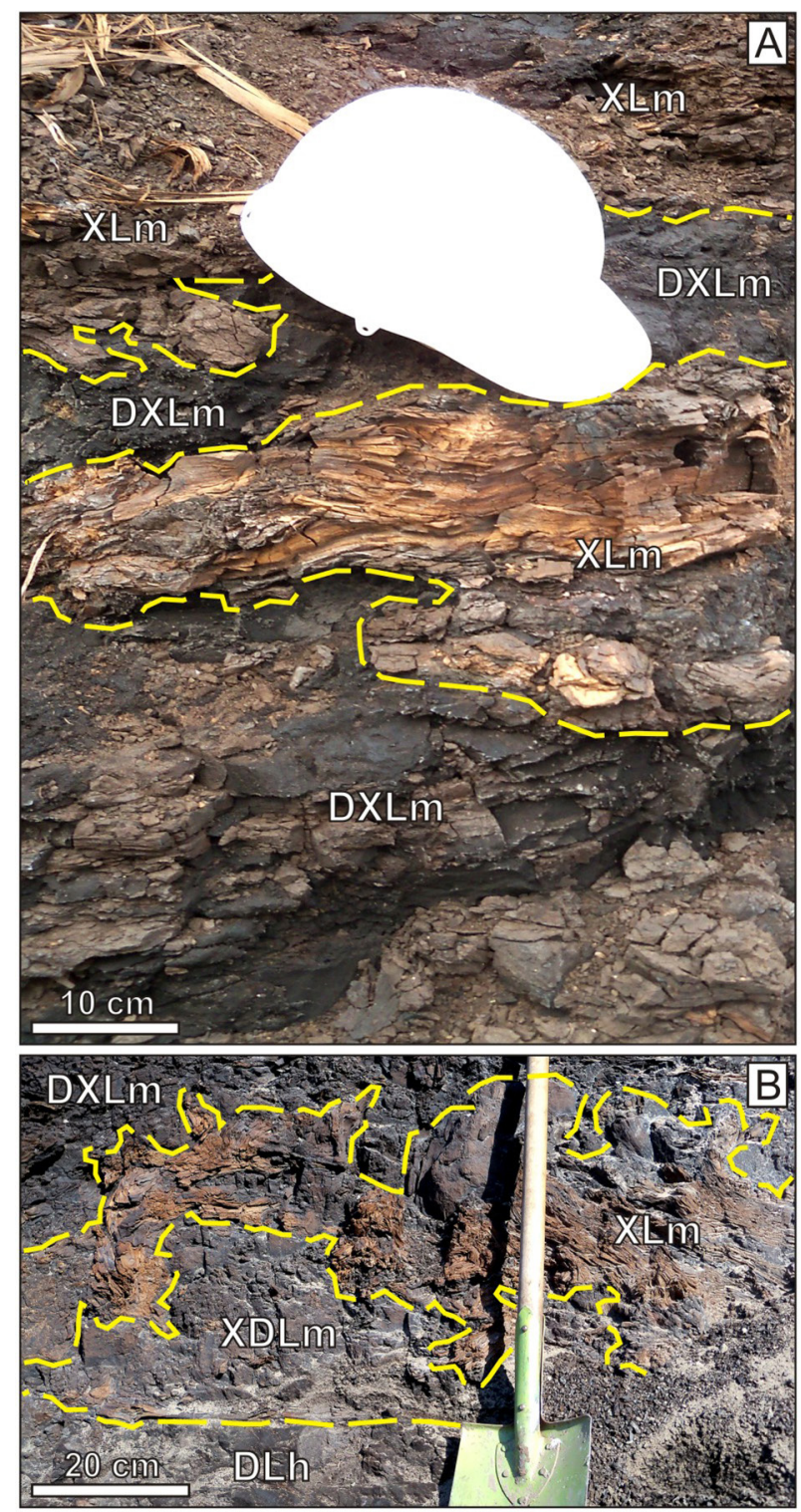

Fig. 4. Xylitic and detroxylitic lignites with a massive structure. A - 1st Middle-Polish Lignite Seam (MPLS1) in the Tomisławice opencast mine, Konin Lignite Mine (white hard hat for scale); B - 1st Middle-Polish Lignite Seam (MPLS-1) in the Koźmin N opencast mine, Adamów Lignite Mine. For location see Figure 1 , for stratigraphical position of the lignite seam see Figure 2 and for explanation of lignite lithotype association codes see Table 1.

Sontag \& Suss (1976), Brzyski (1981), Wolf (1988), Kwiecińska \& Wagner (1997), Markič \& Sachsenhofer (1997), Taylor et al. (1998), Kolcon \& Sachsenhofer (1998, 1999), Ticleanu et al. (1999), Markič et al. (2001), Widera (2012) and Flores (2013). Detailed criteria for distinguishing lignite lithotypes and their best-developed examples among the currently exploited Polish lignite seams are discussed below. 


\section{Characteristics of lignite lithotype associations in Poland}

\subsection{Xylitic lignite association (XL)}

\subsubsection{Description}

The xylitic lignite association is characterised by the presence of more than $90 \%$ (' $10 \%$ rule') fossilised wood particles, that is, xylites. They must be macroscopically distinguishable woody fragments that are larger than $1 \mathrm{~cm}$, such as stumps, trunks, branches, twigs and cones. They are usually light to dark brown in colour and their internal structure is easily visible (Figs. 3, 4). Obviously, the remainder of the lithotype forms the matrix, which consists of black, amorphous, fine-detrital organic matter and woody particles smaller than $1 \mathrm{~cm}$ in diameter (Kwiecińska \& Wagner, 1997). The horizontal, gelified and deformed structures may characterise the xylitic lignites. However, the commonest and typical feature of this lithotype association is a massive structure (compare Figs. 3, 4).

\subsubsection{Interpretation}

Based on the pioneering research of Teichmüller (1958), when the lignite lithotype is known, an initial mire type can be roughly defined. Thus, the xylitic lignite association corresponds to a dry forest swamp as the original depositional environment (Teichmüller, 1958, 1989).

The presence of xylitic lignites within a seam, especially the so-called 'stump horizons', provides a convincing record of dry conditions in mire evolution when the ground water-table was relatively low (e.g. Ticleanu et al., 1999; Diessel et al., 2000). Such horizons with stump remains of Taxodium, Juniperus and Glyptostrobus are exceptionally well developed in the Turów opencast mine within ŚLS-3 and LLS-2 (Kasiński et al., 2010). In other opencasts, the xylites most often lie horizontally (trunks, branches, twigs), either in growth position (stumps, roots) or arranged chaotically (Figs. 3, 4). Xylitic lignites are occasionally found within Polish lignite seams, that is, forming up to $10 \%$ of seam thickness (Widera, 2014a, 2014b). This is due to the fact that the dry forest swamp is characterised by environmental conditions that are favourable for the decomposition of plant remains rather than their accumulation (Brzyski, 1981).

\subsection{Detritic lignite association (DL)}

\subsubsection{Description}

In contrast to the lithotype described above, the detritic lignite association contains at least $90 \%$ (' $10 \%$ rule') plant detritus. It is predominantly of a dark grey to black colour (Figs. 3A, C; 4B). The remainder of this lignite association consists of other lithotypes. These are most often xylites, which are distributed irregularly within the detritic matrix. Therefore, a massive structure is the most characteristic of the detritic lignite association. Other structures, including a gelified one, are also very common in some cases (Figs. 5A, 5B). This specific structure also applies to the gelified xylites (Fig. 5C).

\subsubsection{Interpretation}

The detritic lignite association most often formed in mire subenvironments related to a fen, open water or a treeless reed marsh (Teichmüller, 1958, 1989). The parent organic material for the creation of this lithotype association could be aquatic plants, sedges and reed-like vegetation, respectively (Kolcon \& Sachsenhofer, 1999; Ticleanu et al., 1999). However, woody vegetation cannot be excluded as the parent material for the detritic lignite, especially in the case of a high degree of plant decomposition.

Here, a gelified lignite should be briefly discussed, which is clearly visible in some parts of ŚLS-3 and LLS-2 at the Bełchatów, Szczerców, and Turów opencast mines (Figs. 5A-C; Wagner et al., 1983; Kasiński, 2000; Kasiński et al., 2010). Effects of the gelification process rarely occur in other Polish lignite opencasts (Fig. 5D; Bechtel et al., 2007; Fabiańska \& Kurkiewicz, 2013). The gelification can be produced by both geochemical and biochemical processes such as the decay of fossil wood. In the first case, the organo-mineral compounds are formed during the progressive doppleritisation of fossil wood (e.g., Brzyski, 1981; Wagner, 1982). In the latter case, the humic acids are transformed into purely organic compounds, that is humins, due to enhanced microbial activity (e.g., Wagner et al. 1983; Diessel, 1992; Bechtel et al., 2003, 2007). The result of these processes is an amorphous, black and intensively glassy substance; hence, it can be easily distinguished in the field (Fig. 5A-D).

\subsection{Detroxylitic lignite (DXL) and xylodetritic lignite (XDL) associations}

\subsubsection{Description}

Both associations consist of an admixture of xylites and fine-detrital matrix, amounting to a total content of more than $90 \%$ according to the '10\% rule' (Kwiecińska \& Wagner, 1997; Kolcon \& Sachsenhofer, 1998). In the case of detroxylitic lignite, xylites prevail over organic detritus. In contrast, xylodetritic lignite is in fact detritic lignite 

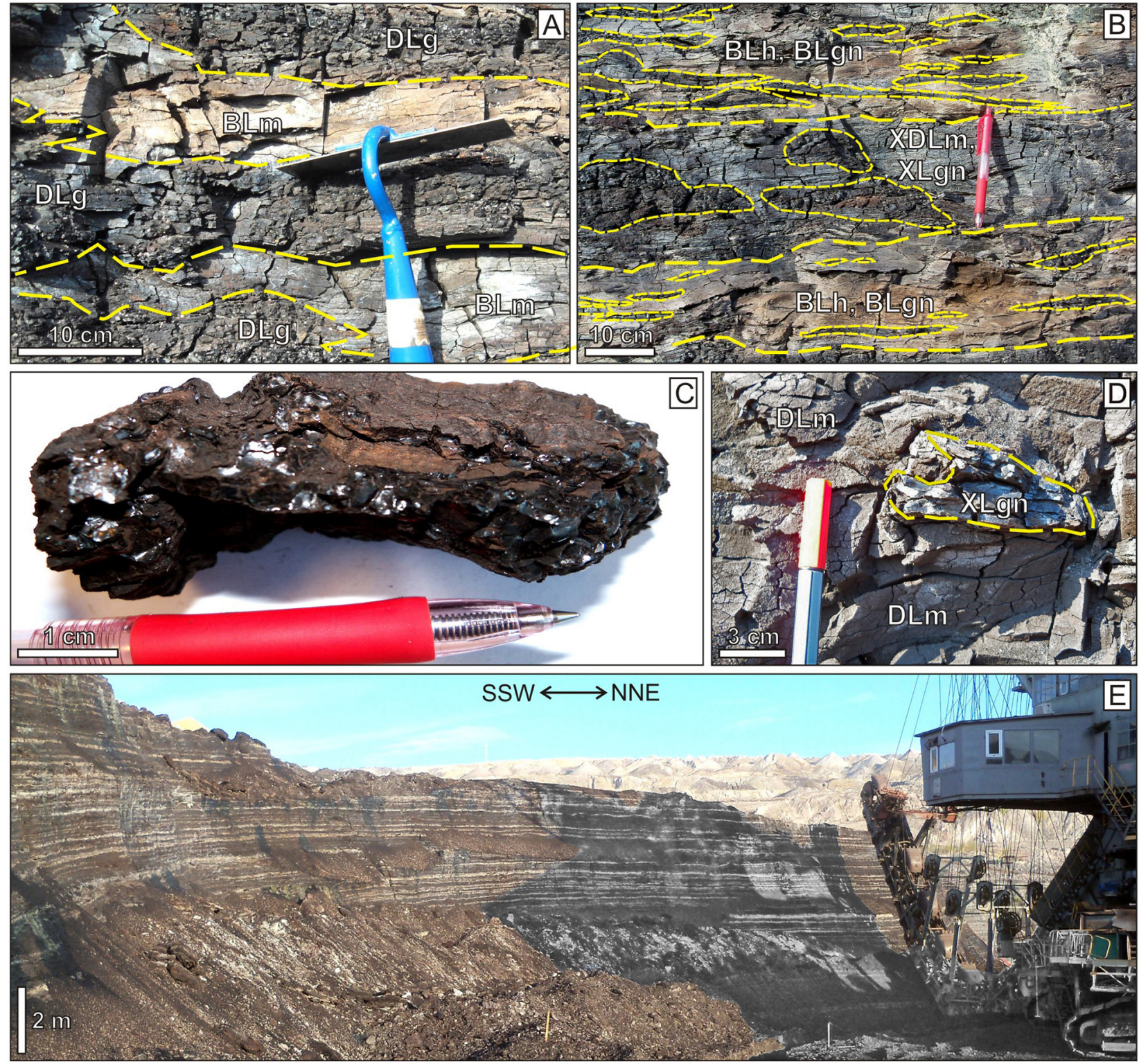

Fig. 5. Bitumen-rich (bituminiferous) lignite with gelified and other structures. A, B - Interbedded bitumen-rich lignite lithotypes with gelified lignite lithotypes in the Turów opencast mine, Turów Lignite Mine; C - Well-gelified xylite fragment from the 3rd Ścinawa Lignite Seam (ŚLS-3) in the Bełchatów opencast mine, Bełchatów Lignite Mine; D - poorly gelified xylite fragment from the 1st Middle-Polish Lignite Seam (MPLS-1) in the Drzewce opencast mine, Konin Lignite Mine; E - General view of the 3rd Ścinawa Lignite Seam (ŚLS-3) in the Turów opencast mine, Turów Lignite Mine. Note the layered structure of lignite seam (bitumen-rich lignite lithotype associations - lighter layers; other lignite lithotype associations - darker layers). For location see Figure 1, for stratigraphical position of the lignite seams see Figure 2 and for explanation of lignite lithotype associations codes see Table 1.

with a considerable amount of xylites (Brzyski, 1981; Widera, 2012). These lithotype associations may represent all the structures that are typical of the examined Polish lignites (Table 1).

\subsubsection{Interpretation}

These two lithotype associations represent transitional environmental conditions between dry forest swamp and open water. Thus, detroxylitic lignites are attributable to the wet forest swamp, whereas xylodetritic lignites are typical of the bush moor (e.g. Diessel, 1992; Kolcon \& Sachsenhofer, 1999). According to the nomenclature proposed by Teichmüller $(1958,1989)$, they can also be called the Taxodium-Nyssa and Myricaceae-Cyrillaceae swamps, respectively. Moreover, the water table 
had to change from a long-lasting and low level to a relatively high level with respect to the mire surface (e.g. Diessel et al., 2000).

Detroxylitic and xylodetritic lignites are the commonest lithotype associations among Polish lignites. In some cases they constitute more than $85 \%$ of the lignite's seam thickness. This situation occurs in some sections of MPLS-1 in the opencasts belonging to the Adamów Lignite Mine (Nowak, 2012).

\subsection{Bitumen-rich lignite association (BL)}

\subsubsection{Description}

In the literature, the bitumen-rich lignite is also known as sapropelic coal, clayey coal or pyropissite (Ticleanu et al., 1999; Kasiński, 2000). It is also divided by Wagner (1996) into bituminiferous and semi-bituminiferous lignite. It has a characteristic colour that can vary from pale yellow to yellowish grey (Fig. 5A, 5B). Thus, it contrasts sharply with other lithotypes in vertical section. On the other hand, the bitumen-rich lignite layers extend laterally from a few dozen to a few hundred metres (Fig. $5 \mathrm{E})$. Due to its origin, it is mostly characterised by a massive or horizontal structure. In the latter case, the lamination is often underlined by strongly gelified strings or lenses (Fig. 5B).

\subsubsection{Interpretation}

Petrographic features of the bitumen-rich (bituminiferous) lignite indicate that phytoplankton sedimentation took place in small and shallow lakes occurring on the mire surface (Wagner, 1996). However, some researchers believe that this lithotype association formed in the shallow, coastal zone of the vast lakes (e.g. Traverse, 1988; Kasiński et al., 2010). More organic matter could be deposited in shallower water $(<2 \mathrm{~m})$, while sedimentation of mineral particles such as clays predominated in deeper water (> 2 m) (e.g. Smith et al., 1989; Diessel et al., 2000).

The bitumen-rich lignite is well developed within ŚLS-3 and LLS-2 in the Bełchatów, Szczerców, and Turów opencast mines. Its macroscopically estimated amount is the largest, attaining up to $30 \%$ of seam thickness, in the case of ŚLS-3 in the Turów opencast mine (Fig. 5E; Wagner, 1996; Kasiński, 2000, Kasiński et al., 2010). However, the total geological resources of Polish bitumen-rich lignites were calculated to be merely about $0.64 \mathrm{Mt}$ at the end of 2014 (Szuflicki et al., 2015).

\subsection{Fusitic lignite association (FL)}

\subsubsection{Description}

The fusitic lignite is characteristically black or silky black, friable with needle-shaped particles, and highly porous (Wolf, 1988; Markič \& Sachsenhofer, 1997; Kolcon \& Sachsenhofer, 1999). Therefore, its bulk density is very low (average 0.3-0.6 $\mathrm{g} / \mathrm{cm}^{3}$ ), allowing it to be easily distinguished from other lithotypes (average $>1.1-1.3 \mathrm{~g} / \mathrm{cm}^{3}$ ). Generally, the fusitic lignite is rare within Polish lignite seams, an exception being the Sieniawa opencast mine, where it forms a few well-developed horizons that are up to $5-10 \mathrm{~cm}$ thick (Fig. 6A-C). The fusitic lignite creates lenses more frequently than it does continuous strata. Its structure may be different; however, it is predominantly nodular (Fig. 6C, D).

\subsubsection{Interpretation}

In essence, the fusitic lignite is a fossil charcoal that is produced by the combustion of plant matter by both exogenous and endogenous processes. In the former case, the dry parts of the mires may be set alight by lightning or volcanic eruptions. In the latter, spontaneous combustion of a lignite seam can be caused by bacterial activity or pyrite oxidation. In any case, the presence of fusitic lignite in the seam is evidence of natural fires in a mire or within the lignite seam (e.g., Brzyski, 1981; Kwiecińska \& Wagner, 1997; Ticleanu et al., 1999; Majewski, 2002).

\subsection{Weathered lignite association (WL)}

\subsubsection{Description}

The distinction of this lithotype association is sometimes very useful in the field; which is why it is added to the present paper (compare Widera, 2012). It is easy to distinguish from other lithotype associations on account of its colour, which is mostly yellowish brown to reddish brown (Fig. 7A). Moreover, it forms a continuous layer over a stretch of at least several tens of metres and a thickness of up to $50 \mathrm{~cm}$. This lithotype association can be characterised by various structures that are typical of all Polish lignites (Fig. 7; Table 1); however, only a folded structure has been documented (Fig. 7A).

\subsubsection{Interpretation}

The weathered lignite results from moisture deficiency on the mire surface. The upper layers of fresh peat were then oxidized under arid conditions, when the groundwater table was relatively low and/or long-lasting droughts occurred. There- 


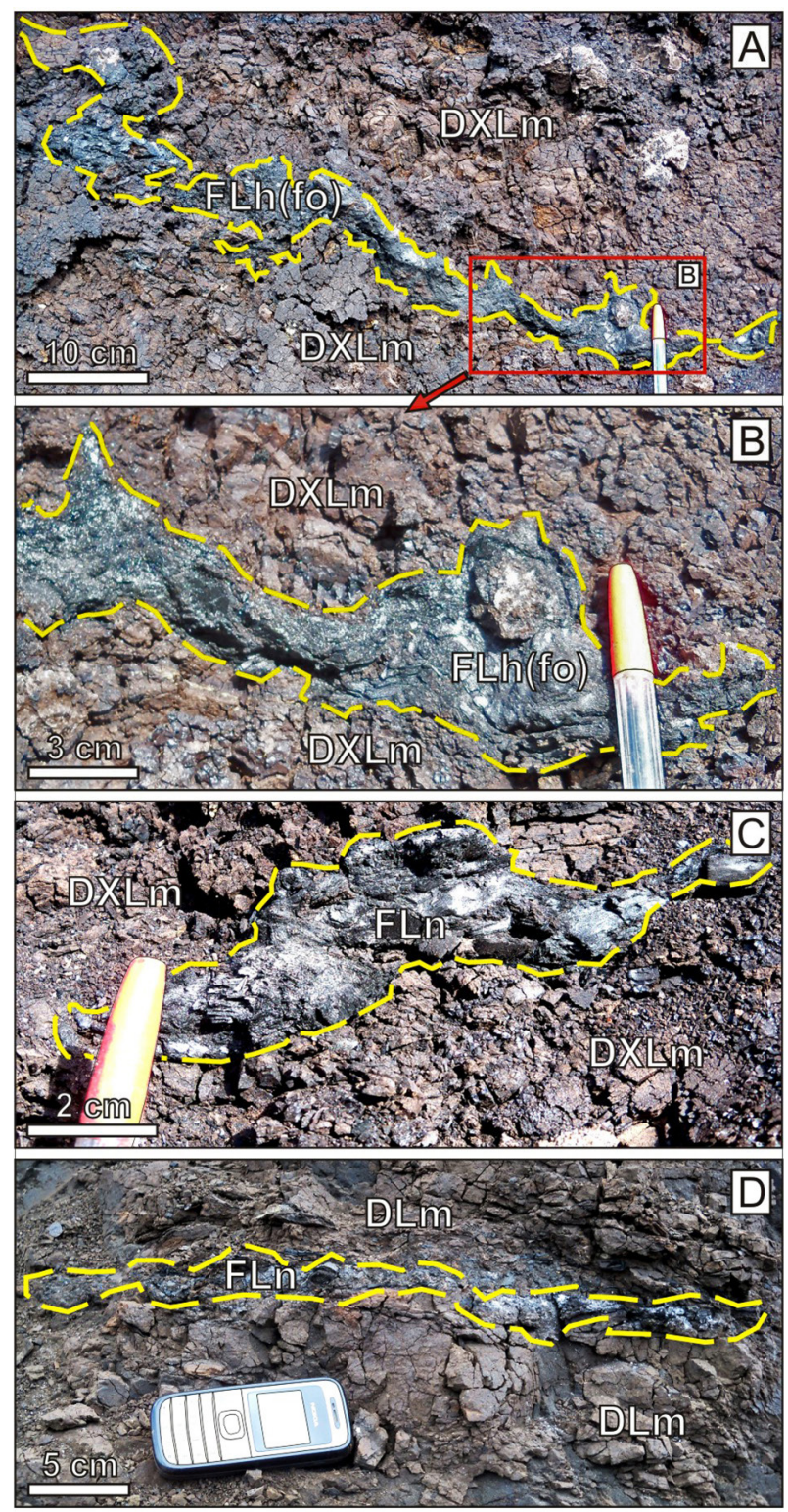

Fig. 6. Fusitic lignites with a folded and nodular structure. A, B, C - Examples of fusitic lignites from the 2nd Lusatian Lignite Seam (LLS-2) in the Sieniawa opencast mine, Sieniawa Lignite Mine; D - Fusitic lignite from the 1st Middle-Polish Lignite Seam (MPLS1) in the Drzewce opencast mine, Konin Lignite Mine. For location see Figure 1, for stratigraphical position of the lignite seams see Figure 2 and for explanation of lignite lithotype associations codes see Table 1.

fore, this type is often accompanied by the fusitic lignite described above. Theoretically, the peat/ lignite roof could also be partly weathered under a thin overburden by infiltration of oxidised water downwards from the land surface. The weathered lignite is well developed only within ŚLS-2 at the Sieniawa opencast mine (Fig. 7A). Conversely, this lithotype association is sporadically recorded from lignite seams at other Polish opencast mines (Kwiecińska \& Wagner, 1997).

\section{General lithotype composition of lignite seam exploited}

Among the currently exploited Polish lignite seams, the highest content of xylites is within MPLS-1 in all opencasts of the Konin and Adamów lignite mines. It has a xylite content of about $8 \%$ (by volume, i.e. roughly equal to the 2-dimensional; compare Fig. 3), including almost $4 \%$ fibrous xylites. Conversely, ŚLS-3 and LLS-2 are characterised by a total xylite content of less than $7 \%$ and a fibrous xylite content of less than 1\% (Bielowicz, 2013). However, the xylite content in some sections may range from $40 \%$ in LLS-2 in the Turów opencast to $55 \%$ in ŚLS-3 and LLS-2 (which, together, create the so-called main coal seam) in the Bełchatów opencast (Wagner, 1996).

In the case of lithotype composition, it should be stated that the lignite seams exploited differ significantly from each other (Table 2). In the Turów opencast, for instance, ŚLS-3 consists of 33.5\% xylodetritic lignite (XDL) and $27.2 \%$ detritic lignite (DL). This is in contrast to ŚLS-3 and LLS-2 from the Bełchatów mine, where the above lithotype associations together contain $34.2 \%$ detroxylitic lignite (DXL) and 30.4\% xylodetritic lignite (XDL). However, the sum of these two lithotype associations (that is, DXL and XDL), is very similar in the case of lignites from the Bełchatów and Sieniawa mines. MPLS-1 is extracted only at the Konin and Adamów mines. It varies from the older lignites mentioned that represent ŚLS-3 and LLS-2. Moreover, MPLS1 differs between the two mines. It consists of $42 \%$ DL at the Konin Lignite Mine, but $85 \%$ XDL in the Adamów Lignite Mine (Table 2).

The contribution of other lithotype associations within the lignites examined also appears of interest, although it varies greatly. First, the relatively high percentage $(9.8-11.8 \%)$ is a share of bitumen-rich (bituminiferous) lignite in seams ŚLS-3 and LLS-2 exploited in the Bełchatów and Turów opencasts. Second, weathered (WL) and fusitic (FL) lignites are also present in the Sieniawa opencast. Macroscopically, these lithotype associations are easily noticeable there, because they comprise $13 \%$ and less than $1 \%$ of the thickness of LLS-2, respectively (compare Table 2 and Figs 6A-C, 7A).

Finally, the size and degree of gelification of the Polish lignite seams require a few words here. The 

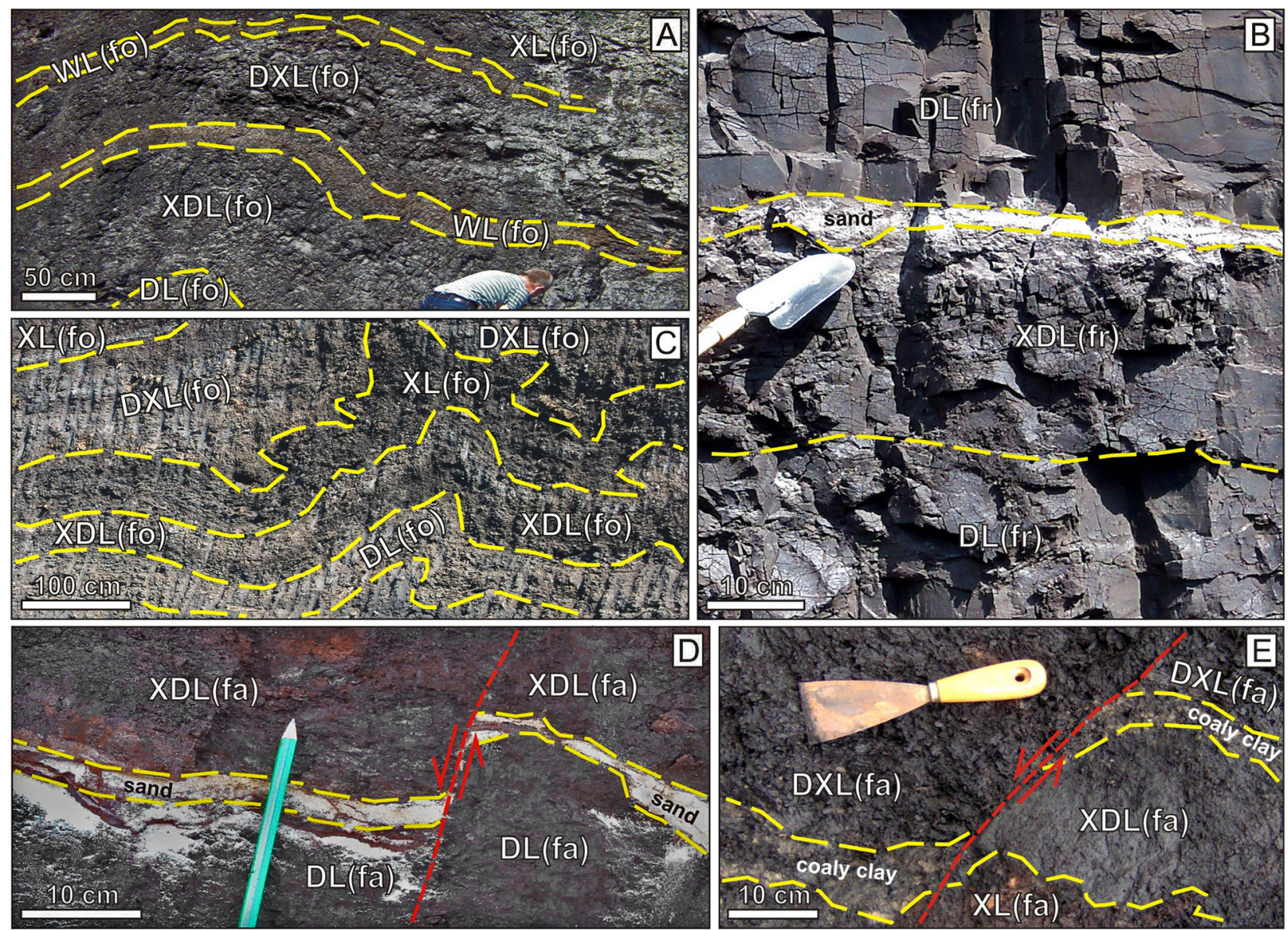

Fig. 7. Lignite lithotype associations with a deformed structure of various origin. A - Glaciotectonically folded lignites within the 2nd Lusatian Lignite Seam (LLS-2) in the Sieniawa opencast mine, Sieniawa Lignite Mine; B - Fractured detritic and xylodetritic lignites - the fractures represent face and butt cleats within the 1st Middle-Polish Lignite Seam (MPLS-1) in the Jóźwin IIB opencast mine, Konin Lignite Mine; C - Lignites folded by the weight of huge, peat-forming trees within the 1st Middle-Polish Lignite Seam (MPLS-1) in the Drzewce opencast mine, Konin Lignite Mine; D - Faulted lignites within the 2nd Lusatian Lignite Seam (LLS-2) in the Sieniawa opencast mine, Sieniawa Lignite Mine; E - Faulted lignites within the 3rd Ścinawa Lignite Seam (ŚLS-3) in the Bełchatów opencast mine, Bełchatów Lignite Mine. For location see Figure 1, for stratigraphical position of the lignite seams see Figure 2 and for explanation of lignite lithotype associations codes see Table 1.

Table 2. Average composition of lithotype associations of currently exploited Polish lignites (after various authors). For location of lignite mines see Figure 1, for explanation of lignite lithotype associations codes see Table 1 and for explanation of lignite seam codes see the text.

\begin{tabular}{|c|c|c|c|c|c|c|}
\hline \multirow{2}{*}{$\begin{array}{l}\text { Lithotype } \\
\text { association }\end{array}$} & \multicolumn{2}{|c|}{ Turów Lignite Mine ${ }^{1}$} & \multirow{2}{*}{$\begin{array}{c}\text { Bełchatów } \\
\text { Lignite Mine }^{1} \\
\text { ŚLS-3 \& LLS-2 }\end{array}$} & \multirow{2}{*}{$\begin{array}{c}\text { Sieniawa } \\
\text { Lignite Mine }^{2} \\
\text { LLS-2 }\end{array}$} & \multirow{2}{*}{$\begin{array}{c}\text { Konin } \\
\text { Lignite Mine }^{3} \\
\text { MPLS-1 }\end{array}$} & \multirow{2}{*}{$\begin{array}{c}\text { Adamów } \\
\text { Lignite Mine }^{4} \\
\text { MPLS-1 }\end{array}$} \\
\hline & ŚLS-3 & LLS-2 & & & & \\
\hline$X L$ & $6.3 \%$ & $7.6 \%$ & $3.0 \%$ & $3 \%$ & $10 \%$ & $3 \%$ \\
\hline DL & $27.2 \%$ & $4.6 \%$ & $20.6 \%$ & $15 \%$ & $42 \%$ & $10 \%$ \\
\hline DXL & $7.0 \%$ & $22.6 \%$ & $34.2 \%$ & $28 \%$ & $35 \%$ & $2 \%$ \\
\hline XDL & $33.5 \%$ & $22.7 \%$ & $30.4 \%$ & $40 \%$ & $10 \%$ & $85 \%$ \\
\hline $\mathrm{BL}$ & $11.8 \%$ & $11.5 \%$ & $9.8 \%$ & no data & no data & no data \\
\hline FL & present & present & present & $<1 \%$ & $<0.1 \%$ & present \\
\hline WL & present & present & present & $13 \%$ & no data & no data \\
\hline
\end{tabular}

${ }^{1}$ - acc. to Wagner $(1996) ;{ }^{2}$ - this paper; ${ }^{3}$ - acc. to Widera $(2012,2014 a, 2014 b) ;{ }^{4}$ - acc. to Nowak (2012). 
lignites from the Turów and Bełchatów mines generally are more strongly gelified than those from the Konin and Adamów mines (Fabiańska \& Kurkiewicz, 2013). This simply means that ŚLS-3 and LLS-2 are much more gelified than MPLS-1. Furthermore, the degree of gelification increases from the bottom of SLS-3 to the roof of LLS-2 in the Bełchatów, Szczerców, and Turów opencasts. Conversely, LLS2 in the Sieniawa opencast is weakly gelified. In this case, it is more closely similar to MPLS-1 from the Konin and Adamów mines than LLS-2 and/or ŚLS3 from the Bełchatów and Turów mines.

\section{Discussion}

\subsection{Lignite lithotype associations vs lignite seam stratigraphy}

The macroscopically estimated composition of the lithotype associations is very different for ŚLS3, LLS-2 and MPLS-1, which are currently mined in Poland. There is no close relationship between the lithotype associations examined and the stratigraphical position of the lignite seams. Generally, xylodetritic (XDL) and detroxylitic (DXL) lignites, which together constitute $40.5-87 \%$ of the seam thickness, predominate among Polish lignites (Table 2). The average content of fibrous xylites differs strongly in various stratigraphically lignite seams. Thus, the youngest seam, MPLS-1, includes at least four times more fibrous xylites than the older ones, LLS-2 and ŚLS-3 (Bielowicz, 2013). Most likely, the lithotype composition is rather the result of the original plant assemblages than a reflection of age and/or stratigraphical position of the examined Miocene-aged lignite seam.

Predominantly, the presence of fusitic and weathered lithotype associations within the lignite seams is evidence of the dry environmental conditions during development of the mire. Both of these lithotype associations are definitely the commonest in the Sieniawa mine (compare Table 2 and Figs 6A-C, 7A). The bitumen-rich lignite cannot be also related to the stratigraphy of the lignite seams. This opinion confirms the lack of this lithotype association within LLS-2 at the Sieniawa mine, although its content within LLS-2 and ŚLS-3 in the Bełchatów and Turów mines is $9.8-11.8 \%$ (Table 2; Wagner, 1996).

Similar to the bitumen-rich lignite, the gelified structure does not exist or is negligible in lignites from the Sieniawa mine. Conversely, it is very characteristic of coeval and older lignites from the
Bełchatów and Turów mines (compare Fig. 5A-D). Therefore, the stratigraphical position of the lignite seams studied does not directly determine its degree of gelification.

\subsection{Lignite lithotype associations vs lignite seam location}

The relationship between the peat-forming environments and the resultant lignite lithotype associations generally does not depend on stratigraphy (as discussed above) or location of the exploited lignite seams. It is possible to indicate such a close dependence in at least two cases that are related to the bitumen-rich and gelified lignites, which are present in the Bełchatów and Turów mines but not in the Sieniawa mine. Because of their practical importance and scientific specificity they need to be discussed here.

In the case of the bitumen-rich lignites (BL), the similarities of those from the Bełchatów and Turów mines are easily noted. Moreover, differences between the Bełchatów and Turów bitumenrich lignites and lignites from the Sieniawa mine are very large (compare Table 2). As stated above, the bitumen-rich lignite formed in the shallow water of lakes that covered the mire surface or existed in close proximity to the mire (compare Traverse, 1988; Wagner, 1996; Kasiński et al., 2010). Therefore, the discussed similarities and differences can be explained by various palaeogeographies of the lignite-bearing areas in Poland during the formation of ŚLS-3 and LLS-2. At that time, the mires developed in the proximity of relatively long-lasting lakes in the vicinity of Bełchatów and Turów lignite deposits. On the other hand, the area of the Sieniawa lignite deposit was located at some distance from such lakes during deposition of LLS-2.

Strong gelification of lignites from the Bełchatów and Turów mines corresponds strictly to their location. It should be noted that the lignite seams examined (ŚLS-3 and LLS-2) are located in tectonic grabens, which are $>500$ and $>250 \mathrm{~m}$ deep, respectively (e.g., Kasiński, 2000; Kasiński et al., 2010; Widera \& Hałuszczak, 2011; Widera, 2016a, 2016b). However, the cause of such a high degree of gelification is different in each case under consideration.

ŚLS-3 and LLS-2 (the main coal seam) from the Bełchatów mine are strongly gelified due to the very high calcium (Ca) content in some parts of the mire. The source of $\mathrm{CaCO}_{3}$ lay in carbonate Jurassic and Cretaceous rocks that are elevated around the lignite deposit. Thus, it seems plausible that 
$\mathrm{CaCO}_{3}$ was supplied to the graben from its margins (e.g. Wagner, 1996; Wagner et al., 2000; Mastej et al., 2015). This explanation is consistent with the opinion of other researchers, who assumed a close relationship between mire alkalinity and degree of lignite gelification (e.g., Diessel, 1992; Markič \& Sachsenhofer, 1997; Bechtel et al., 2003).

The Turów lignite deposit is located in the northeastern segment of the Eger (Ohře) Graben (e.g., Kasiński, 2000; Kasiński et al., 2010; Widera, 2016b). It is surrounded and underlain by Precambrian and Cenozoic volcanic rocks. On the other hand, the degree of gelification is considerably stronger at the bottom of SLS-3 than at the roof of LLS-2 as mentioned above. Therefore, the increased degree of geothermal energy in southwest Poland, especially during Early-Middle Miocene volcanic activity, is most likely responsible for the very strong gelification of lignites in the Turów mine (compare Fig. 5A, 5B).

Finally, it is noteworthy that the bitumen-rich (bituminiferous) lignites and gelified lignites have advantages and disadvantages during the utilisation process. Their presence within the studied seams significantly increases the lignite's calorific value, which is closely associated with a higher rank of coal/lignite. Some parts of the seams with high quantities of the bitumen-rich and gelified lignites are characterised by limited usefulness, for instance, in the process of underground gasification. On the other hand, a relatively large amount of fibrous xylites is also undesirable in lignite mining, combustion and possible gasification. This is because fibrous xylites make it difficult for chain excavators to work, are characterised by lower calorific value than other lithotypes, and are hard to grind in the process of lignite combustion and gasification (e.g., Wagner, 1996; Kwiecińska \& Wagner, 1997, 2001; Bielowicz, 2013; Bielowicz \& Kasiński, 2014).

\section{Conclusions}

Polish lignites are highly diversified lithologically and petrologically. The currently exploited lignite seams represent a wide range of lithotypes with characteristic textural and structural features. Each of these lithotype associations corresponds or may be related to specific environmental conditions of peat deposition. Such peat-forming environments and the resultant lignite lithotypes are known from all humic ortholignites of low-rank coal deposits around the world.

In most cases there was no correlation between the lithotype associations' composition and the stratigraphy of the investigated lignite seams or between the lithotype associations' composition and the location of these seams. Such a close relationship was found only with respect to the bitumen-rich and gelified lignites from the Bełchatów and Turów mines. In the case of the former, this is explained by the palaeogeographical conditions. The increased degree of gelification within the lignite seams in these two mines is linked to mire alkalinity in the Bełchatów Lignite Mine and to the degree of geothermal energy in the Turów Lignite Mine.

In summary, the lithotype associations' composition is important for mining activities and multi-use of lignite. An accurate description of the currently exploited lignite seams, including the determination of lithotypes, may not only be of great importance for scientific knowledge but also useful for present or future utilisation of lignite in Poland. Therefore, further studies of lignite lithotypes are encouraged.

\section{Acknowledgements}

I am grateful to Professor Marian Wagner (AGH University of Science and Technology, Kraków, Poland) for discussion and clarification of several issues related to lignite petrography. Furthermore, reviewers are thanked for their comments and suggestions that improved the quality of the present paper.

\section{References}

Bechtel, A., Sachsenhofer, R.F., Markič, M., Gratzer, R., Lücke, A. \& Püttmann, W., 2003. Palaeoenvironmental implications from biomarker and stable isotope investigations on the Velenje lignite seam (Slovenia). Organic Geochemistry 34, 1277-1298.

Bechtel, A., Widera, M., Sachsenhofer, R.F., Gratzer, R., Lücke, A. \& Woszczyk, M., 2007. Biomarker and stable carbon isotope systematic of fossil wood from the 2nd Lusatian lignite seam of the Lubstow deposit (Poland). Organic Geochemistry 38, 1850-1864.

Bielowicz, B., 2013. Petrographic composition of Polish lignite and its possible use in a fluidized bed gasification process. International Journal of Coal Geology 116-117, 236-246.

Bielowicz, B. \& Kasiński, J.R., 2014. The possibility of underground gasification of lignite from Polish deposits. International Journal of Coal Geology 131, 304-318.

Brzyski, B., 1981. Klasyfikacja megaskopowa i charakterystyka odmian trzeciorzędowego węgla brunatnego z obszaru Polski [Megascopic classification and description of Tertiary brown coal varieties from Polish territory]. Geologia 7, 5-30. 
Ciuk, E., 1968. Types of brown coal deposits within coal-bearing formations of continental tertiary of Poland. 23rd Geological Congress, Prague, 119-134.

Ciuk, E. \& Piwocki, M., 1990. Mapa złóż węgli brunatnych i perspektywy ich występowania w Polsce w skali 1:500 000 [Map of brown-coal deposits and prospect areas in Poland, scale 1:500,000]. Państwowy Instytut Geologiczny, Warszawa.

Diessel, C., 1992. Coal-Bearing Depositional Systems. Springer-Verlag, Berlin, $721 \mathrm{pp}$.

Diessel, C., Boyd, R., Wadsworth, J., Leckie, D. \& Chalmers, G., 2000. On balanced and unbalanced accommodation/peat accumulations ratios in the Cretaceous coals from Gates Formation, Western Canada, and their sequence-stratigraphic significance. International Journal of Coal Geology 43, 143-186.

Fabiańska, M.J. \& Kurkiewicz, S., 2013. Biomarkers, aromatic hydrocarbons and polar compounds in the Neogene lignites and gangue sediments of the Konin and Turoszów Brown Coal Basins (Poland). International Journal of Coal Geology 107, 24-44.

Flores, R.M., 2013. Coal and Coalbed Gas: Fueling the Future. Elsevier, Amsterdam, 697 pp.

Grimm, K., Grimm, M., Huss, M., Jansen, F., Prüfert, A., Gürs, K., Lietzow, A., Ritzkowski, S., Standke, G., Blumenstengel, H., Bülow, W., Hottenrot, M., Doppler, G., Heissig, K., Reichenbacher, B. \& Schwerd, K. (Eds), 2002. Tertiary. [In:] German Stratigraphic Commission. Stratigraphic Table of Germany 2002.

ICCP (International Committee for Coal Petrology), 1993. International handbook of coal petrography. $3^{\text {rd }}$ supplement to $2^{\text {nd }}$ ed. University of Newcastle upon Tyne, England.

Kasiński, J.R., 2000. Geological atlas of the Tertiary lignitebearing association in the Polish part of the Zittau Basin. Polish Geological Institute, Warsaw.

Kasiński, J.R. \& Piwocki, M., 2002. Low rank coals in Poland: prospection, mining, progress. [In:] J. Jureczka \& M. Podemski (Eds), Proceedings of the IV European Coal Conference. Polish Geological Institute Special Papers 7, 18-30.

Kasiński, J.R., Piwocki, M., Swadowska, E. \& Ziembińska-Tworzydło, M., 2010. Charakterystyka węgla brunatnego z miocenu Niżu Polskiego na podstawie wybranych profile [Lignite of the Polish Lowlands Miocene: characteristics on a base of selected profiles]. Biuletyn Państwowego Instytutu Geologicznego 439, 99-154.

Kolcon, I. \& Sachsenhofer, R.F., 1998. Coal petrography and palynology of the Early Miocene lignite seam from the opencast mine Oberdorf ( $\mathrm{N}$ Voitsberg, Styria, Austria). [In:] F.F. Steininger (Ed.): The Early Miocene lignite deposits of Oberdorf, N Voitsberg (Styria, Austria). Jahrbuch der Geologischen Bundesanstalt 140, 433-440.

Kolcon, I. \& Sachsenhofer, R.F., 1999. Petrography, palynology and depositional environments of the early Miocene Oberdorf lignite seam (Styrian Basin, Austria). International Journal of Coal Geology 41, 275-308.

Kwiecińska, B. \& Wagner, M., 1997. Typizacja cech jakościowych węgla brunatnego z krajowych złóż wedtug kryteriów petrograficznych $i$ chemiczno-technologicznych dla celów dokumentacji geologicznej złóż oraz obstugi kopalń [Classification of qualitative features of Brown coal from Polish deposits according to petrographical, chemical and technological criteria]. Wydawnictwo Centrum PPGSMiE Polskiej Akademii Nauk, Kraków, 87 pp.

Kwiecińska, B. \& Wagner, M., 2001. Możliwość zastosowania refleksyjności jako metody badawczej w klasyfikowaniu $i$ technologicznej ocenie jakości węgla brunatnego [Application of reflectance in natural and technological classification of brown coal (lignite)]. Wydawnictwo Akademii Górniczo-Hutniczej, Kraków, 35 pp.

Majewski, S., 2002. Fuzyn w węglu brunatnym złóż: Mosty, Rzepin i Torzym [Fusain in the lignite deposits: Mosty, Rzepin and Torzym]. Geologia 28, 165-176.

Markič, M. \& Sachsenhofer, R.F., 1997. Petrographic composition and depositional environments of the Pliocene Velenje lignite seam (Slovenia). International Journal of Coal Geology 33, 229-254.

Markič, M., Zavšek, S., Pezdič, J., Skaberne, D. \& Kočevar, M., 2001. Macropetrographic characterization of the Velenje Lignite (Slovenia). Acta Universitatis Carolinae, Geologica 45, 81-97.

Mastej, W., Bartuś, T. \& Rydlewski, J., 2015. Analysis of lithofacies cyclicity in the Miocene Coal Complex of the Bełchatów lignite deposit, south-central Poland. Geologos 21, 285-302.

Nowak, N., 2012. Kartowanie profili geologicznych w odkrywce węgla brunatnego Koźmin [Mapping of the geological profiles in the Koźmin lignite opencast]. MSc Thesis, Institute of Geology, Adam Mickiewicz University, Poznań, $71 \mathrm{pp}$.

Pietraszewski, A., 2015. Polskie górnictwo węgla brunatnego w 2014 roku [Polish lignite mining industry in 2014]. Węgiel Brunatny 90, 4-14.

Piwocki, M., 1992. Zasięg i korelacja głównych grup trzeciorzędowych pokładów węgla brunatnego na platformowym obszarze Polski [Extent and correlations of main groups of the Tertiary lignite seams on Polish platform area]. Przeglad Geologiczny 40, 281-286.

Piwocki, M. \& Ziembińska-Tworzydło, M., 1997. Neogene of the Polish Lowlands - lithostratigraphy and pollen-spore zones. Geological Quarterly 41, 21-40.

Smith, N.D., Cross, T.A., Dufficy, J.P. \& Clough, S.R., 1989. Anatomy of an avulsion. Sedimentology 36, 1-23.

Sontag, E. \& Suss, M., 1976. On the macropetrographic analysis of soft brown coals. Pt II. Recommendations for an international classification system for soft brown coals. Zeitschrift für Angewandte Geologie 22, 313-319.

Suss, M. \& Sontag, E., 1966. On the petrographic nomenclature and systematic classification of soft brown coals. Bergbautechnik 16, 186-190.

Szuflicki, M., Malon, A. \& Tymiński, M. (Eds), 2015. Bilans zasobów złóż kopalin w Polsce wg stanu na 31 XII $2014 r$. [The balance of mineral resources deposits in Poland as of 31.12.2014]. Państwowy Instytut Geologiczny, Warszawa, 1-473,

Taylor, G.H., Teichmüller, M., Davis, A., Diessel, C.F.K. Littke, R. \& Robert, P., 1998. Organic Petrology. Borntraeger, Berlin-Stuttgart, 704 pp. 
Teichmüller, M., 1958. Rekonstruktion verschiedener Moortypen des Hauptflözes der niederrheinischen Braunkohle. Fortschrift in der Geologie von Rheinland und Westfalen 2, 599-612.

Teichmüller, M., 1989. The genesis of coal from the viewpoint of coal petrology. International Journal of Coal Geology 12, 1-87.

Ticleanu, N., Scradeanu, D., Popa, M., Milutinovici, S., Popa, R., Preda, I., Ticleanu, M., Savu, C., Diaconita, D., Barus, T., Petrescu, I., Dinulescu, C. \& Maftei, R., 1999. The relation between the lithotypes of Pliocene coals from Oltenia and their main quality characteristics. Bulletin of the Czech Geological Survey 74, 169-174.

Traverse, A., 1988. Paleopalynology. Unwin Hyman, Boston, $600 \mathrm{pp}$.

Vinken, R. (Ed.), 1988. The Northwest European tertiary basin, results of the IGCP. Project No. 124. Geologisches Jahrbuch A100.

Wagner, M., 1982. Doppleritization of xylitic coal in the light of petrographic and chemical investigations. International Journal of Coal Geology 2, 181-194.

Wagner, M., 1996. Węgiel brunatny bitumiczny ze złóż Turów i Bełchatów w świetle badań petrograficzno-chemicznych i sedymentologicznych [The bituminiferous lignite from the Turów and Bełchatów brown coal deposits and its petrographic-chemical and sedimentological studies]. Prace Geologiczne PAN 143, 7-107.

Wagner, M., Słomka, T. \& Doktor, M., 2000. Skład petrograficzny i warunki sedymentacji wapieni jeziornych ze złoża węgla brunatnego Bełchatów [Petrographic composition and conditions of sedimentation of lacustrine limestones from the Bełchatów lignite deposit]. [In:] T. Słomka \& M. Wagner (Eds): Charakter petrograficzny $i$ warunki sedymentacji wybranych kompleksów litologicznych z profilu miocenu w złożu wegla brunatnego Betchatów [Petrological studies and sedimentological conditions of select lithologic series in Miocene from Betchatów lignite deposit, Poland]. Prace Geologiczne PAN 147, 47-73.

Wagner, M., Żerda, T. \& John, A., 1983. Żelifikacja węgla ksylitowego w świetle badań petrograficznych i fi- zyczno-chemicznych [Gelification in the light of petrographic and physico-chemical studies]. Kwartalnik Geologiczny 27, 87-104.

Widera, M., 2007. Litostratygrafia i paleotektonika kenozoiku podplejstoceńskiego Wielkopolski [Lithostratigraphy and palaeotectonics of the sub-Pleistocene Cenozoic of Wielkopolska]. Adam Mickiewicz University Press, Poznań, $224 \mathrm{pp}$.

Widera, M., 2012. Macroscopic lithotype characterisation of the 1st Middle-Polish (1st Lusatian) Lignite Seam in the Miocene of central Poland. Geologos 18, 1-11.

Widera, M., 2014a. What are cleats? Preliminary studies from the Konin lignite mine, Miocene of central Poland. Geologos 20, 3-12.

Widera, M., 2014b. Lignite cleat studies from the first Middle-Polish (first Lusatian) lignite seam in central Poland. International Journal of Coal Geology 131, 227238.

Widera, M., 2016a. Depositional environments of overbank sedimentation in the lignite-bearing Grey Clays Member: New evidence from Middle Miocene deposits of central Poland. Sedimentary Geology 335, 150-165.

Widera, M., 2016b. Genetic classification of Polish lignite deposits: A review. International Journal of Coal Geology 158, 107-118.

Widera, M., Ćwikliński, W. \& Karman, R., 2008. Cenozoic tectonic evolution of the Poznań-Oleśnica Fault Zone, central-western Poland. Acta Geologica Polonica 58, 455-471.

Widera, M. \& Hałuszczak, A., 2011. Stages of the Cenozoic tectonics in central Poland: examples from selected grabens. Zeitschrift der Deutschen Gesellschaft für Geowissenschaften 162, 203-214.

Wolf, M., 1988. Torf und Kohle. [In:] H. Füchtbauer (Ed.): Sedimente und Sedimentgesteine. Teil II. Schweizerbart, Stuttgart, 683-730.

Manuscript received: 10 February 2016 Revision accepted: 12 September 2016 